\title{
RAINWATER HARVESTING IN DRY CHACO: REGIONAL DISTRIBUTION AND LOCAL WATER BALANCE
}

Patricio N. Magliano ${ }^{\mathrm{a}}$, Francisco Murray ${ }^{\mathrm{a}, \mathrm{b}}$, Germán Baldi ${ }^{\mathrm{a}}$, Santiago Aurand ${ }^{\mathrm{c}}$, Ricardo A. Páez ${ }^{\mathrm{a}}$, Wilbert Harder ${ }^{\mathrm{d}}$, Esteban G. Jobbágy ${ }^{\mathrm{a}}$

a. Grupo de Estudios Ambientales - IMASL, Universidad Nacional de San Luis and CONICET. Ejército de los Andes 950, D5700HHW. San Luis, SL, Argentina.

b. INTA, UEyDT San Luis, Ruta 20 tramo R. Hernández, SL, Argentina.

c. INTA, EEA San Luis. Ruta 7 y 8, Villa Mercedes, San Luis, SL, Argentina.

d. Servicio Agropecuario Paraguayo - Chortitzer Komitee. Avenida Ultima C. Central, Loma Plata, BO, Paraguay.

* Corresponding author: Patricio N. Magliano. Tel: +54-266-4520325, Fax +54-2664422803, web: http://gea.unsl.edu.ar

E-mail:pnmagliano@gmail.com 


\begin{abstract}
Rainwater harvesting (RWH) has been essential for the establishment of human settlements in many dry regions of the world that lacked suitable surface or ground water resources. A vast fraction of the South American Dry Chaco ecoregion still relies on RWH to support, not only livestock production, but domestic and industrial uses as well. As a result, water capture and storage infrastructure is widely disseminated throughout the region. In this paper we characterized the most typical RWH systems in two contrastingly developed sub-regions of Dry Chaco, ranging from extensive ranching to intensive beef and dairy production (central Argentina and western Paraguay, respectively). In each sub-region, we quantified RWH systems density, spatial distribution and associations with landscape features; furthermore, we illustrated how the daily dynamic of water stock in a typical RWH system contributes to assess their capture and storage efficiency. We found that randomly distributed low sophisticated RWH systems prevailed in central Argentina, while clustered distributed high sophisticated ones were more common in western Paraguay. RWH systems density was ten times higher in western Paraguay (0.94 vs. 0.098 units $/ \mathrm{km}^{2}$ ), showing an exponential association with land cleared fraction and proximity to villages. The daily dynamic of water stock of the RWH impoundment showed that water harvest events were exponentially associated with precipitation magnitude events $\left(R^{2}=0.86\right)$, while annual water losses were explained by infiltration and evaporation fluxes (59 vs. $41 \%$, respectively). Across both sub-regions, RWH accounts for less than $1 \%$ of the annual precipitation, playing a minor role on the regional water balance; however at a local level, they can affect several hydrological fluxes including the onset of groundwater recharge and the mitigation of extreme runoff events.
\end{abstract}

Keywords: Impoundment, catchments, runoff, evaporation, infiltration, drylands 


\section{Introduction}

Drylands, where available water is the main limitation for primary productivity, spread over more than one third of the global continental surface (Noy-Meier, 1973; Weltzin et al., 2003). In these regions, the water balance is primarily determined by the ratio between precipitation and evapotranspiration (Huxman et al., 2004), while runoff or deep drainage represent only a very small fraction of the water balance equation (Whitford, 2002; Scanlon et al., 2005; Newman et al., 2010). Furthermore, the combination of low precipitation, negligible deep drainage and large amounts of salt stored in the vadose zone, make groundwater scarce, deep, and often salty in most of these systems (Scanlon et al., 2005; Contreras et al., 2012; Marchesini et al., 2013), unless remote sources of recharge exist (Jobbágy et al., 2011). In contraposition, runoff, although representing a small flux of water balance, can generate, at patch or stand scales, an important surface water redistribution flux (Breshears and Barnes, 1999; Wilcox et al., 2003; Ludwig et al., 2005), representing the only source of freshwater supply in many cases (Evenari et al., 1971; Lavee et al., 1997; Hoff et al., 2010). The process of harvesting these small runoff fraction by human is known as "rainwater harvesting" (hereafter, RWH) (Pandey et al., 2003; Oweis and Hachum, 2009; UNEP, 2009; Denison and Wotshela, 2012).

The RWH process has three stages: (i) rainwater capture and transport, (ii) storage, (iii) distribution and use (FAO, 1991; Ngigi, 2003; Oweis and Hachum, 2009). These stages involve two key landscape features: an area that generates runoff (catchment), and an area that collects and stores it (storage) (Boers and Ben-Asher, 1982; Zhang et al., 2013). Catchment and storage areas can be part of the natural landscape or can require substantial infrastructure (Scanlon and Goldsmith, 1997; Li et al., 2004). In dry sedimentary plains, catchment areas are often generated or expanded unintentionally by roads and livestock trails, but also by ad-hoc human interventions. Similarly, storage areas can be natural topographic depressions or man-made excavations that are enclosed to prevent horizontal surface water losses, receiving in this paper the general denomination of impoundments.

Some of the major challenges for RWH in dry sedimentary plains are (i) typical low runoff rates and with high temporal variability, which usually amplifies the already high 
variability of precipitation inputs, (ii) high soil infiltration rates, which reduce catchment yield and storage efficiency which is also reduced by (iii) high evaporation rates (Noy-Meier, 1973; Nicholson, 2011). Through history, many communities have found different solutions for these challenges. To overcome low runoff, dedicated catchment areas have been developed by eliminating their green cover and compacting and channeling their terrain. In order to reduce infiltration and evaporation from storage areas, farmers opted to compact the bottom and established tree belts (Abu-Awwad and Shatanawi, 1997; Abu-Zreig et al., 2000; Li and Gong, 2002). More extreme alternatives to escape evaporation include underground storage in cisterns or induced recharge to the water table, which offers large storage capacity but substantial hydraulic losses as well (Junker, 1996; Von Hoyer et al., 2000; Duarte et al., 2003; Tymkiw, 2010). All this progress on the efficiency of RWH systems have led to the improvement of production and rural life quality in many drylands in Africa, Asia and Australia (Mbilinyi et al., 2005; Zhang et al., 2009; Eroksuz and Rahman, 2010; Malik et al., 2014).

The Dry Chaco ecoregion, with almost one million of square kilometers, represents one of the largest and flattest sedimentary areas under semiarid climate of the planet (slopes of $<0.1 \%$ ) (Adamoli et al., 1990; Jobbágy et al., 2008). In this region, runoff represents a minor flux of the annual water balance, however, several studies have described exceptional runoff events during summer storms (Aguilera et al., 2003; Kunst et al., 2003; Sanzano et al., 2008; Harder, 2013). In addition, unlike the adjoining Pampa plains with a more humid climate and a grassland cover, Dry Chaco hosts deep and salty groundwater over most of the territory (Pasig, 2005; Jobbágy et al., 2008; Weins, 2013). For these reasons, rural settlers and farmers rely on RWH as the only source of fresh water for human and livestock consumption. However, fresh water availability is still constraining the efficient use of forage in the less developed areas of the region (Harder, 2013; Rueda et al., 2013). The regional diversity of production systems (Baldi et al., 2014) is often accompanied by their own typical RWH technology (Duarte et al., 2003; Basán Nickisch, 2010; Harder, 2013). As a result of this, Dry Chaco has a short history of RWH (in comparison, for example, with China, India or Israel), but a great local development of systems with different sizes, shapes and degrees of technology (from very primitive and inexpensive to very complex and highly sophisticated). 
In this paper, we characterize structural and functional attributes of RWH systems in two sub-regions of Dry Chaco sharing very similar hydrological environments and prevalence of grazing as the major land use fraction, but experiencing contrasting development trends and productive intensification pathways; these are the central Argentina and the western Paraguay. In both sub-regions we: (i) characterize general aspects of RWH systems, including their catchment and storage infrastructure; (ii) quantify their density, spatial distribution and association to landscape features; and (iii) illustrate how the daily dynamic of water stock in a typical RWH system helps to assess its capture and storage efficiency.

\section{Materials and methods}

Dry Chaco is located in central-northern Argentina, western Paraguay and south-eastern Bolivia (Morello and Toledo, 1959; Morello and Adámoli, 1974). The original vegetation of xeric forests and savannas dependant on soil and climate patterns has been modified by a short history of human disturbances such as wood extraction, fire and grazing (Gasparri and Baldi, 2013; Rueda et al., 2013). Soils are derived from the massive accumulation of fine loess and alluvial sediments from the Andes Mountains during the Quaternary (Toby Pennington et al., 2000). Climate is subtropical, with a spring-summer rainy season (September to March), annual precipitation ranging from 400 to $1100 \mathrm{~mm} / \mathrm{year}$, and an aridity ranging from 0.3 to 0.7 according to the precipitation to potential evapotranspiration ratio (Maldonado et al., 2006; Magliano et al., 2015).

This work focuses on two sub-regions of Dry Chaco with similar climatic characteristics and prevalence of grazing as the major land use fraction, but that differ in their population density and intensity of livestock production (Gasparri and Grau, 2009; Gime'nez et al., 2014). These are central Argentina (northwest of the province of San Luis, latitude $-34^{\circ}$ to $-32^{\circ}$, longitude $-67^{\circ}$ to $-65^{\circ}$ ) and western Paraguay (the Mennonite colonies, latitude $-25^{\circ}$ to $-19^{\circ}$, longitude $-62^{\circ}$ to $-58^{\circ}$ ) (Fig. 1). In central Argentina extensive cattle breeding is the most common activity ( 0.15 animal units per ha), performed with a very low investment level and using the native forest as the main forage resource. In some sites of this sub-region, RWH systems, become gradually 
replaced by remote water sources coming from wetter regions or from nearby mountain systems based on state-centralized infrastructure. Western Paraguay, instead, where ranching has been highly intensified over the last five decades due to the establishment of Mennonite colonies, followed a strong endogenous development trend where high sophisticated RWH systems have emerged. The livestock production is based on more intensive grazing systems which involve cattle breeding and fattening and dairy production with higher stocking rates (0.75 animal units per ha), larger investment levels, more infrastructure and a large fraction of the landscape devoted to planted pastures (Glatzle and Cabrera, 1996; Glatzle and Stosiek, 2001; Aguilera, 2003). Furthermore, the increased intensity in livestock production was accompanied by higher population density, greater accessibility and connectivity and the development of local beef and dairy processing industries (Harder, 2013).

Insert Fig. 1 here, please

\section{Sampling procedure}

In order to characterize different types of RWH systems, quantify their density and spatial distribution, and analyze their associations with landscape features at a regional level, we conducted our sampling within discontinuous circular cells of $10 \mathrm{~km}$ of radius ( 31,500 ha; $n=14$ and 15 in central Argentina and western Paraguay, respectively; Fig. 1). Cells maintained a $10 \mathrm{~km}$ distance from each other and excluded exceptional land cover types (i.e. salt pans and hilly areas). All analyses were summarized by study region.

Within cells, we mapped the point location of each RWH system ( $n=4,958$ points) based on an "on-screen" visual interpretation of very high $(\leq 1 \mathrm{~m}$, mostly Quickbird and WorldView) to high (2.5-10 m, Spot) spatial resolution images from Google Earth (Ploton et al., 2012; Baldi et al., 2013). Even though differences in sensor, acquisition date and visual geometry, or visual treatment across study sites, RWH systems were easily detected by the combination of small regular areas (square or circular-shaped) with low to high brightness depending on the level of accumulated water (i.e. the impoundment), surrounded by a bare soil area with high brightness (i.e. the catchment area). In Figure 2 are shown different RWH systems appearance from imagery and field 
photographs. Visual interpretation was complemented with field surveys conducted during 2011 in central Argentina and 2012 in western Paraguay. Then, we characterized the RWH systems (including catchment areas and impoundments) from a random select sample of $2 \%$ of the total mapped (see below).

\section{i) $R$ WH systems characterization}

We determined three types of impoundments and five types of catchment areas. Impoundments were named "horseshoes", "rectangles" and "compounds". The horseshoes consist of arched embankments built 2-4 meters above the ground surface with an open section facing the top of the slope, where runoff water is captured (Fig. 2A). The rectangles consist of excavations with straight edges and a relatively constant depth (Fig. 2B). The compounds are composed by a rectangle and circular tank elevated 2-10 meters above the ground surface (Fig. 2C), in which harvesting includes two stages, first, the runoff water is captured by the rectangle, and second, it is pumped into the circular tank where it is stored for extended periods. We calculated the mean and the coefficient of variation (CV) of the storage capacity for each type of impoundment as the product of its area and its height, considering horseshoes and rectangles as rectangular or square prisms, and circular tanks as truncated cones. The volume of the compounds was obtained as the sum of the volume of its two component parts (rectangle and circular tank). Data for area calculation (length and width, for the case of horseshoes and rectangles, and diameter, for the case of circular tanks) were measured from satellite images. To calculate the height, a fixed value of $0.8 \mathrm{~m}$ and $1.0 \mathrm{~m}$ for horseshoes and rectangles, respectively, was used, and the circular tank height was estimated as the $15 \%$ of its diameter. These values are based on field measurements during our surveys $(n=12,6$, and 9 for horseshoes, rectangles and compounds, respectively) and review of technical literature and unpublished data in the case of the circular tanks in central Paraguay. However, some of these values are approximate, because impoundments loose a little of its storage capacity every year due to the accumulated sediment transported by runoff. So, ranchers have to remove it from the impoundment, typically every five to ten years.

The identified catchment areas types were "paleorivers", "livestock trails", "vehicle roads", "dedicated areas", and "indefinite". Note that, given the gentle slope of the 
region $(<0.1$, in a lot of cases), was impossible to determine the catchment area for each impoundment, even with high resolution digital elevation models. Paleorivers represent beds of ancient rivers that no longer flow, usually as a result of their progressive siltation process. Some of these paleorivers carry water temporarily after intense precipitation events (Fig. 2D). Livestock trails include networks of tracts of bare and compacted ground that converge to water spots. They are spontaneously developed by livestock as it moves from grazing to watering areas and work as catchments when located upslope of the impoundments (George et al., 2004; Karlin, 2013). Very often, these trails are associated with highly degraded zones around the impoundments (Macchi and Grau, 2012) (Fig. 2E). Vehicle roads are usually unpaved tracts used for local traffic. Their layout is generally straight and along their side a slightly depressed area collets runoff. In many of them, small dams are made to divert water more efficiently to the impoundments (Fig. 2F). Dedicated areas comprise surfaces of the landscape that are specifically transformed to magnify runoff. Typically, vegetation is at least partially removed, soil is compacted, and small channels built to increase runoff and transport it to the impoundment (Fig. 2G).

Insert Fig. 2 here, please

\section{ii) Spatial patterns of RWH systems}

Within each circular cell, we assessed the density of RWH systems and their degree of spatial aggregation through the Ripley's L function (a transformation of Ripley's K function that stabilizes variance and facilitates interpretation) (Wiegand and Moloney, 2004; Ripley, 2005).This spatial pattern analysis, commonly used in geostatistics, describes the characteristics of the pattern of point distributions over a variable range of distances, showing whether RWH systems are located in random, clustered, or dispersed patterns. In order to statistically test if points were randomly distributed in space (Poisson distribution), spatial pattern were compared with the spatial pattern expected under the null model of complete randomness by generating confidence bands using Monte Carlo simulations (99 randomizations). Values above or below those predicted under the null model indicate clustering or dispersion, respectively. Finally, for each sub-region, we estimated how random, clustered, or dispersed patterns changed with increasing distance from each RWH system (visual examples are shown in Appendix I). 
In order to better understand the spatial associations of RWH systems with landscape variables, we calculated for each circular cell (a) the fraction of the landscape under a dry forest or a cleared land cover, and (b) the mean Euclidean distance from human infrastructure (paved or unpaved roads and villages). Data came from the most updated and accurate available information, i.e. the land cover/land use maps (UMSEF, 2008; Paraguay, 2013; Vallejos et al., 2014) and infrastructure maps (MAPEAR, 2013). Associations were explored through standard linear regression approaches, and model selection was carried out through the Akaike's information criterion (Akaike, 1974).

\section{iii) Dynamics of water stock in a typical RWH system}

Temporal high-frequency measurements of the water level were obtained a typical horseshoe impoundment (coordinates -33.2133; -66.4744, central Argentina). During the study period there was no animal or human consumption. Precipitation, radiation, temperature, relative humidity and wind speed, were recorded with an automatic meteorological station located $1.5 \mathrm{~km}$ away from the impoundment. Monitoring was carried out throughout a 18-month period (2011-2013), covering two wet seasons (SepMar) and one dry season (Mar-Aug). To record water level, an automatic pressure sensor with datalogger (Onset Hobo, resolution $\pm 1 \mathrm{~mm}$ water column) was installed at the bottom of the impoundment, programmed to make recordings every 30 minutes. Daily tank evaporation was calculated using records form the meteorological station, adapting the Penman-Monteith method (Allen et al., 1998). Field precipitation data was supplemented with TRMM satellite data (product 3V42-V7 derived, http://disc2.nascom.nasa.gov/Giovanni/tovas/), which integrates an area of $625 \mathrm{~km}^{2}$ (Kummerow et al., 1998). A detailed topographic survey of the impoundment was performed in order to link the water level to the water volume stock changes. In order to develop a level vs. volume function, we divided the impoundment into a grid of 5 x 5 meters (total 135 points) and measured the distance from the water surface to the bottom of the impoundment at each point, when the impoundment was full of water (March, 2013). We defined events of water gain as periods with a $>2 \mathrm{~mm} /$ day rise. The relationship between the volume gained in each of these events and the precipitation of those periods was established using a simple regression. Then, we correlated the impoundment water losses to tank evaporation and absolute water level in order to 
determine the relative influence of evaporative demand and bottom infiltration driving losses.

\section{Results}

\section{i) $R W H$ systems characterization}

Central Argentina and western Paraguay hosted different predominant types of RWH systems (Table 1). In central Argentina, the most common system was the horseshoe, associated with livestock trails and vehicle roads. Both types of catchment areas coexist and hence their sum exceeds $100 \%$. Only $6 \%$ of the impoundments in this sub-region were rectangles and no compounds, paleorivers and dedicated areas were found. In western Paraguay the most frequent RWH system was the rectangle associated with vehicle roads. This sub-region showed a larger diversity of RWH systems, as a product of the combination of the three types of impoundments and four types of catchment areas. Compounds, despite representing $24 \%$ of observed RWH systems, hosted more than half of the water harvested in the entire sub-region, due to the large individual storage capacity. Catchments types associated with compounds were mainly vehicle roads, and to a lesser extent, dedicated areas. In the last case, we observed a strong and significant linear relationship between storage capacity of the compound and surface of the dedicated area $\left(\mathrm{R}^{2}=0.67, \mathrm{p}<0.0001, \mathrm{n}=44\right)$, revealing a slope of $2,000 \mathrm{~m}^{3}$ of storage capacity per ha of dedicated capture area. This suggests that, on average, a capture of $200 \mathrm{~mm} /$ year (net runoff generation in dedicated area) would saturate the storage structure.

Insert table 1 here, please

\section{ii) Spatial patterns of RWH systems}

The mean density of RWH systems was an order of magnitude higher in western Paraguay, where a more intensive activity takes place, than in central Argentina, which represents the most extensive and widespread production systems of Dry Chaco (Table 2). The high mean density found in western Paraguay was heavily influenced by a few 
cells, as reflected by the difference between the mean and the median values, while central Argentina was less variable in this aspect (Table 2). The averaged rainwater storage capacity was $0.44 \mathrm{~mm} /$ year in central Argentina and $3.5 \mathrm{~mm} / \mathrm{year}$ in western Paraguay, representing, in both sub-regions, less than $1 \%$ of annual precipitation (mean annual rainfall: $\sim 400$ and $\sim 800 \mathrm{~mm} /$ year, for central Argentina and western Paraguay, respectively; TRMM regional data). These values were obtained by dividing the average storage capacity doubled $\left(\mathrm{m}^{3}\right)$, assuming that the impoundments are filled on average twice a year in both sub-regions (Supported by interviews with local farmers during field visits), and the average of the surface occupied by only one RWH system $\left(\mathrm{m}^{2}\right.$; 1/RWH systems density; Table 2).

\section{Insert table 2 here, please}

The spatial distribution of RWH systems was predominantly random in central Argentina and clustered in western Paraguay (Fig. 3). In central Argentina a scaledependency was found, with RWH systems distributed both randomly and clustered at close distances $(<4 \mathrm{~km})$, and both randomly and dispersed at greater distances $(>4 \mathrm{~km})$. In western Paraguay, however, characteristic cores of settlement and production explained the spatial distribution of RWH systems (Fig. 4). The density of RWH systems showed a positive and significant association with the cleared surface land (Fig. $4 ; \mathrm{R}^{2}=0.53 ; \mathrm{p}<0.0001$ ) and to the proximity to villages (Fig. $4 ; \mathrm{R}^{2}=0.56 ; \mathrm{p}<0.0001$ ), whereas no significant association with road density was found.

Insert Fig. 3 and 4 here, please

\section{iii) Dynamics of the stock of water in a typical RWH system}

Temporal high-frequency water level measurements on a horseshoe impoundment, fed by a catchment of livestock trails and vehicle roads, contributed to understand water capture and water loss dynamics. Water gains took place as isolated events in response to a complex association with rainfall events, while water losses took place as a continuum daily process produced by evaporation and infiltration (Fig. 5). 
Water gains showed an exponential relationship with the magnitude of the precipitation events (Fig. 6A; $\mathrm{R}^{2}=0.86 ; \mathrm{p}<0.0001$ ). Water harvesting amplified the episodic and high variability of precipitation inputs, as shown by the fact that the five largest precipitation events accounted for $33 \%$ of the total precipitation of the study period, while the five largest water harvest events accounted for $66 \%$ of the total volume gained (Unpublished data). The residuals of the water gains/precipitation relationship highlight notable aspects of water harvesting to be taken into account when improving these systems. First, we found that there were three events of water gains without precipitation records at the impoundment site (points on " $y$ " axis). The spatially disperse nature and elongated shape of trail/road-fed catchments areas, coupled with the spatial variability of precipitation in Dry Chaco, may explain these rare events. The impoundment could be receiving the supply from a precipitation event that affected neighbouring areas but not the impoundment site. Analysis of TRMM precipitation shows that there were precipitation events corresponding to those water gain events, despite not having been detected by the in situ rain gauge. This finding suggests that large and elongated catchments may help to reduce the temporal variability of RWH systems generating connections between distant areas and increasing the probability of receiving precipitation events. Second, we identified the inverse situation, in which three recorded precipitation events generated almost no water gains, even in the case of an event of 27 $m m$ (points near " $x$ " axis). This suggests that dry soil conditions of trails and roads and/or low hourly precipitation intensity may prevent runoff, maximizing infiltration. Finally, and in line with the previous two cases, it is observed, even for large events of similar size precipitation, that a remarkable variation in water gains exist (two events of approx. $60 \mathrm{~mm}$ contributing $450 \mathrm{~m}^{3}$ vs. $800 \mathrm{~m}^{3}$ ). This should be taken into account when projecting safe margins or minimum likely water harvest volumes based on time series of precipitation.

\section{Insert Fig. 6 here, please}

Daily water losses were poorly explained by fluctuations in the daily evaporative demand $(p=0.64)$, but were strongly associated with the absolute water level of the impoundment (Fig. 6B; $\mathrm{R}^{2}=0.85 ; \mathrm{p}<0.0001$ ). When the absolute water level was high, reaching $2 \mathrm{~m}$ above the bottom, losses were in the order of $40 \mathrm{~m}^{3} /$ day, decreasing to $<2$ 
$\mathrm{m}^{3} /$ day when the water level was $<0.5 \mathrm{~m}$. This relation was also found in periods with high and with low evaporative demand, highlighting the importance of water losses by infiltration. During the monitoring period, the impoundment harvested $5260 \mathrm{~m}^{3} /$ year, equivalent to 2.1 times its maximum storage capacity. We estimated, from the calculated values of tank evaporation, that evaporation consumed $41 \%$ of this captured volume while the remaining 59\% was lost through infiltration.

\section{Discussion}

RWH in Dry Chaco has been essential for the human development in the region. As a result of a scarce public or private water distribution infrastructure in the region, local domestic water capture and storage infrastructure is still widely disseminated throughout the region. We found that randomly distributed, low sophisticated RWH systems prevailed in central Argentina, while clustered and high sophisticated systems were more common in western Paraguay. Their density was an order of magnitude higher in western Paraguay, being exponentially associated with land cleared fraction and proximity to villages. The high-frequency monitoring of water stock suggested a positive but complex response of water capture to precipitation. Based on one impoundment data and on field interviews with farmers and local professionals, we suggest that the elongated catchment area, created by roads and trails, could have partially decoupled local precipitation and water yield of the impoundment.

With the exception of the most sophisticated systems of western Paraguay, all the RWH in Dry Chaco is virtually based on catchment areas that are spatially disperse and have elongated shapes defined by vehicle roads, livestock trails and, to a lesser extent, paleoriver beds (Karlin, 2013) (Table 1; field interviews with local professionals). These areas, with very low infiltration rates, concave section and high connectivity, represent a small fraction of the landscape (typically $\sim 1 \%$ ), yet they generate much of the runoff that is stored in the impoundments, due to the landscape matrix (dry forests) has a very small runoff (Aguilera et al., 2003; Kunst et al., 2003; Sanzano et al., 2008; Harder, 2013). The spatially disperse nature and elongated shape of roads/trails make the RHW a variable and unpredictable process, very different from what happens in southern Asia, northern Africa, and also in the few most-developed systems of western Paraguay, where dedicated catchments, of smaller area but more effective capture potential, are 
systematically located next to the impoundments (FAO, 1991; Oweis and Hachum, 2009; Malik et al., 2014). Our analysis of these types of catchment areas in western Paraguay, suggest a generation of $400 \mathrm{~mm} /$ year of mean annual runoff, based on the relationship between their size and the storage capacity of the impoundment, and the fact that this capacity is filled twice in a year. However, it is important to note that the roads/trails have some advantages that could be used to improve the efficiency of water capture: (i) they generate elongated catchments that can partially damp the high spatial variability of precipitation, (ii) they do not require a particular budget beyond those assigned to road maintenance programs, (iii) they can be modified by humans, directly in the case of roads, and through livestock management in the case of trails (Walker and Heitschmidt, 1986).

Livestock movement management oriented to the maximization of water harvesting of trails represents one of the greatest challenges of low sophisticated RWH in Dry Chaco. We suggest that an appropriate management through an intelligent distribution of fences and water spots may, not only maximize forage intake and vegetation growth/protection, but favour runoff conduction towards impoundments. One of the principal factors that determines livestock movement is the location of water points (Valentine, 1947; Ganskopp, 2001; Bailey, 2005), even more important than the amount, quality and spatial distribution of forage (Ganskopp and Bohnert, 2009). In this aspect, the spatial distribution of impoundments, along with the rest of the biophysical characteristics of the environment (vegetation, topography, soils), determine the density and spatial distribution of the trails in the landscape (Walker and Heitschmidt, 1986; Ganskopp et al., 2000). Using these characteristics, inherent to the physiological behaviour of animals, will be key in the design of more efficient grazing systems in order to maximize the water harvesting and production in general. As far as we know, based on personal interviews and discussion with local consulting professionals, this possibility is not being considered in current grazing management. However, in a few cases and in the last years, some ranchers started to situate the impoundment in a topographically low corner of the stand, so livestock can only move from higher areas to the lowest area with the impoundment.

RWH still has a minor role in the regional water balance of Dry Chaco, accounting for less than $1 \%$ of the total precipitation input, however, at local scales it may generate 
major changes in water fluxes by increasing -for example-deep drainage, as a result of infiltration losses from impoundments. The strength of this phenomenon would depend on the density of impoundments. In other dry sedimentary plains of the world, as it is the case of India, with 13 times higher human population density than Dry Chaco and with a longer RWH tradition, these systems have generated water table rises and surface salinization (Kumar et al., 2006; Raju et al., 2006; Dinesh Kumar et al., 2008; Baldi and Jobbágy, 2012; Glendenning et al., 2012). Note that, these two processes go together in most of flat sedimentary drylands, because of the large quantity of salt storage in the vadose zone of the profile (Scanlon et al., 2005; Jobbágy et al., 2008). In Dry Chaco, due to the relatively low mean density of RWH systems (Table 2), no major changes in the ecohydrology of the landscape matrix would occur. However, in the most intensive production cells from western Paraguay, where the overall water capture is 10 times higher than in the rest of Dry Chaco (Fig. 4), preliminary evidence of groundwater recharge and surface salinization near old impoundments were found (Junker, 1996; Von Hoyer et al., 2000; Harder, 2013). Even though these are isolated cases, they could be the beginning of larger changes affecting sustainable water harvesting practices in Dry Chaco; so the monitoring of local groundwater levels and salinity will be critical in the future. Our work showed how monitoring water levels in the impoundments can help to identify significant and risky groundwater recharge fluxes, offering also opportunities to improve water capture and storage (Fig. 6B).

This study has explored the Dry Chaco RWH in two contrastingly developed subregions ranging from extensive ranching to intensive beef and dairy production (central Argentina and western Paraguay, respectively). RWH accounts for less than $1 \%$ of the annual precipitation, playing a minor role on the regional water balance; however at a local level, they can affect several hydrological fluxes, including the onset of groundwater recharge and the mitigation of extreme runoff events along roads and trails. Due to its versatility, independence of public or private large-scale infrastructure and easy access by farmers, RWH seems to continue being the dominant strategy of fresh water supply. In the coming years, and under the scenario of international increasing meat and dairy prices, knowing the amount and the different type of systems, and they ecohydrological impacts at regional and local level, will be a critical step; especially to increase its efficiency and enable the intensification of livestock production, without generating undesirable environmental consequences. 


\section{Acknowledgments}

We thank Jorge Mercau, Marisa Puente, Eva Florio, Roberto Fernández and an anonymous reviewer for their valuable suggestions. We thank Albrecht Glatzle, Wilhelm Giesbrecht and the members of the "Servicio Agropecuario Paraguayo" (Mathew, Lennard, Jenny, Alberto and Mark) for their discussions in the field. We thank Yeye Darvich and Gabriel Fernández for allowing us to work in their fields. This work was funded by the International Development Research Center (IDRC, Canada 1066010010) and ANPCyT-Argentina (PRH 27 PICT 2008-00187). PNM and RP are supported by fellowships from CONICET and IDRC, respectively. EGJ and GB are members of CONICET and UNSL, FM and SA of INTA and WH of SAP. 


\section{References}

Abu-Awwad, A.M., Shatanawi, M.R., 1997. Water harvesting and infiltration in arid areas affected by surface crust: Examples from Jordan. Journal of Arid Environments 37, 443-452.

Abu-Zreig, M., Attom, M., Hamasha, N., 2000. Rainfall harvesting using sand ditches in Jordan. Agricultural Water Management 46, 183-192.

Adamoli, J., Sennhauser, E., Acero, J.M., Rescia, A., 1990. Stress and disturbance: vegetation dynamics in the dry Chaco region of Argentina. Journal of Biogeography 17, 491-500.

Aguilera, M.O., 2003. Uso ganadero de los pastizales naturales de San Luis., in: Panigatti, M.O.A.a.J.L. (Ed.), Con las metas claras. INTA, San Luis, Argentina. Aguilera, M.O., Steinaker, D.F., Demaria, M.R., 2003. Runoff and soil loss in undisturbed and roller-seeded shrublands of semiarid Argentina. Journal of Range Management 56, 227-233.

Akaike, H., 1974. New look at the statistical model identification., IEEE Transactions on Automatic Control AC-19, 716-723.

Allen, R.G., Pereira, L.S., Raes, D., Smith, M., 1998. Crop evapotranspiration-

Guidelines for computing crop water requirements-FAO Irrigation and drainage paper 56. FAO, Rome 300, 6541.

Bailey, D.W., 2005. Identification and creation of optimum habitat conditions for livestock. Rangeland Ecology and Management 58, 109-118.

Baldi, G., Houspanossian, J., Murray, F., Rosales, A.A., Rueda, C.V., Jobbágy, E.G., 2014. Cultivating the dry forests of South America: Diversity of land users and imprints on ecosystem functioning. Journal of Arid Environments.

Baldi, G., Jobbágy, E., 2012. Land use in the dry subtropics: Vegetation composition and production across contrasting human contexts. Journal of Arid Environments 76, 115127.

Baldi, G., Verón, S.R., Jobbágy, E.G., 2013. The imprint of humans on landscape patterns and vegetation functioning in the dry subtropics. Global Change Biology 19, 441-458.

Basán Nickisch, M., 2010. Manejo de recursos hídricos para áreas de secano. Instituto Nacional de tecnología agropecuaria.

Boers, T.M., Ben-Asher, J., 1982. A review of rainwater harvesting. Agricultural Water Management 5, 145-158.

Breshears, D.D., Barnes, F.J., 1999. Interrelationships between plant functional types and soil moisture heterogeneity for semiarid landscapes within the grassland/forest continuum: A unified conceptual model. Landscape Ecology 14, 465-478.

Contreras, S., Santoni, C.S., Jobbágy, E.G., 2012. Abrupt watercourse formation in a semiarid sedimentary landscape of central Argentina: the roles of forest clearing, rainfall variability and seismic activity. Ecohydrology, online.

Denison, J.A., Wotshela, L., 2012. An overview of indigenous, indigenised and contemporary water harvesting and conservation practices in south Africa. Irrigation and Drainage 61, 7-23.

Dinesh Kumar, M., Patel, A., Ravindranath, R., Singh, O.P., 2008. Chasing a mirage: Water harvesting and artificial recharge in naturally water-scarce regions. Economic and Political Weekly 43, 61-71.

Duarte, G., Palmieri, J.H., Frutos, S., Guerrero, J.O., 2003. Estudio de alternativas de abastecimiento de agua para el Chaco Central, Asunción, Paraguay.

Eroksuz, E., Rahman, A., 2010. Rainwater tanks in multi-unit buildings: A case study for three Australian cities. Resources, Conservation and Recycling 54, 1449-1452. 
Evenari, M., Shanan, L., Tadmor, N., 1971. The Negev. The challenge of a desert., Second edition ed. Harvard University Press.

FAO, 1991. Water harvesting, in: Critchley, W., Siegert, K. (Eds.).

Ganskopp, D., 2001. Manipulating cattle distribution with salt and water in large aridland pastures: a GPS/GIS assessment. Applied Animal Behaviour Science 73, 251-262. Ganskopp, D., Cruz, R., Johnson, D., 2000. Least-effort pathways?: a GIS analysis of livestock trails in rugged terrain. Applied Animal Behaviour Science 68, 179-190. Ganskopp, D.C., Bohnert, D.W., 2009. Landscape nutritional patterns and cattle distribution in rangeland pastures. Applied Animal Behaviour Science 116, 110-119.

Gasparri, N.I., Baldi, G., 2013. Regional patterns and controls of biomass in semiarid woodlands: lessons from the Northern Argentina Dry Chaco. Regional Environmental Change, 1-14.

Gasparri, N.I., Grau, H.R., 2009. Deforestation and fragmentation of Chaco dry forest in NW Argentina (1972-2007). Forest Ecology and Management 258, 913-921.

George, M.R., Larsen, R.E., McDougald, N.K., Tate, K.W., Gerlach, J.D., Fulgham, K.O., 2004. Cattle grazing has varying impacts on stream-channel erosion in oak woodlands. California Agriculture 58, 138.

Gime'nez, R., Mercau, J.L., Houspanossian, J., Jobbágy, E.G., 2014. Balancing agricultural and hydrologic risk in farming systems of the Chaco plains. Journal of Arid Environments.

Glatzle, A., Cabrera, A., 1996. Potencial de las pasturas cultivadas en el Chaco Paraguayo, Congreso Internacional de transferencia tecnológica agropecuaria. Glatzle, A., Stosiek, D., 2001. Country Pasture/Forage Resource Profiles. El Lector, Asunción (Paraguay).

Glendenning, C.J., Van Ogtrop, F.F., Mishra, A.K., Vervoort, R.W., 2012. Balancing watershed and local scale impacts of rain water harvesting in India-A review.

Agricultural Water Management 107, 1-13.

Harder, W., 2013. Provisión de Agua para la producción agropecuaria del Chaco

Central, Uso sustentable de los recursos hídricos para la producción agropecuaria del Chaco Paraguayo, Loma Plata, Paraguay.

Hoff, H., Falkenmark, M., Gerten, D., Gordon, L., Karlberg, L., Rockström, J., 2010. Greening the global water system. Journal of Hydrology 384, 177-186.

Huxman, T.E., Snyder, K.A., Tissue, D., Leffler, A.J., Ogle, K., Pockman, W.T., Sandquist, D.R., Potts, D.L., Schwinning, S., 2004. Precipitation pulses and carbon fluxes in semiarid and arid ecosystems. Oecologia 141, 254-268.

Jobbágy, E.G., Nosetto, M.D., Santoni, C.S., Baldi, G., 2008. The ecohydrological challenge of woody-herbaceous transitions in the chaco-pampas plains. El desafío ecohidrológico de las transiciones entre sistemas leñosos y herbáceos en la llanura chaco-pampeana 18, 305-322.

Jobbágy, E.G., Nosetto, M.D., Villagra, P.E., Jackson, R.B., 2011. Water subsidies from mountains to deserts: Their role in sustaining groundwater-fed oases in a sandy landscape. Ecological Applications 21, 678-694.

Junker, M., 1996. Determinación de las características hidrogeológicas y evaluación de la recarga de agua subterránea en el área del Tajamar Serenidad, Filadelfia., Cooperativa Hidológica Paraguaya.

Karlin, M.S., 2013. Hidrología, El Chaco Árido. Marcos Sebastián Karlin, pp. 63-77. Kumar, M.D., Ghosh, S., Patel, A., Singh, O.P., Ravindranath, R., 2006. Rainwater harvesting in India: some critical issues for basin planning and research. Land Use and Water Resources Research 6, 1-17.

Kummerow, C., Barnes, W., Kozu, T., Shiue, J., Simpson, J., 1998. The Tropical 
Rainfall Measuring Mission (TRMM) sensor package. Journal of Atmospheric and Oceanic Technology 15, 809-817.

Kunst, C., R., Ledesma, M., Basan Nickish, G., Angella, D., J., P., Godoy., 2003. Rolado de "fachinales" e infiltración de agua en el Chaco occidental (Argentina). Revista de investigaciones agropecuarias, INTA 32:, 105-126.

Lavee, H., Poesen, J., Yair, A., 1997. Evidence of high efficiency water-harvesting by ancient farmers in the Negev Desert, Israel. Journal of Arid Environments 35, 341-348. Li, X.Y., Gong, J.D., 2002. Compacted microcatchments with local earth materials for rainwater harvesting in the semiarid region of China. Journal of Hydrology 257, 134144.

Li, X.Y., Xie, Z.K., Yan, X.K., 2004. Runoff characteristics of artificial catchment materials for rainwater harvesting in the semiarid regions of China. Agricultural Water Management 65, 211-224.

Ludwig, J.A., Wilcox, B.P., Breshears, D.D., Tongway, D.J., Imeson, A.C., 2005. Vegetation patches and runoff-erosion as interacting ecohydrological processes in semiarid landscapes. Ecology 86, 288-297.

Macchi, L., Grau, H.R., 2012. Piospheres in the dry Chaco. Contrasting effects of livestock puestos on forest vegetation and bird communities. Journal of Arid Environments 87, 176-187.

Magliano, P.N., Fernández, R.J., Mercau, J.L., Jobbágy, E.G., 2015. Precipitation event distribution in central argentina: Spatial and temporal patterns. Ecohydrology 8, 94-104. Maldonado, P., Höhne, E., Naumann, M., Metz, R., Wessling, G., 2006. Atlas del Gran Chaco Americano, p. 98.

Malik, R., Giordano, M., Sharma, V., 2014. Examining farm-level perceptions, costs, and benefits of small water harvesting structures in Dewas, Madhya Pradesh.

Agricultural Water Management 131, 204-211.

MAPEAR, P., 2013. Proyecto MAPEAR: Mapas Electrónicos Argentinos.

Marchesini, V.A., Fernández, R.J., Jobbágy, E.G., 2013. Salt leaching leads to drier soils in disturbed semiarid woodlands of central Argentina. Oecologia 171, 1003-1012.

Mbilinyi, B.P., Tumbo, S.D., Mahoo, H.F., Senkondo, E.M., Hatibu, N., 2005.

Indigenous knowledge as decision support tool in rainwater harvesting. Physics and Chemistry of the Earth 30, 792-798.

Morello, J., Adámoli, J., 1974. Las grandes unidades de vegetación y ambiente del Chaco argentino. Segunda Parte: Vegetación y ambiente de la Provincia del Chaco. INTA Serie fitogeográfica 13.

Morello, J., Toledo, C.S., 1959. El bosque chaqueño I. Paisaje primitivo, paisaje natural y paisaje cultural en el oriente de Salta. Revista Agronómica del Noroeste Argentino 3, 208.

Newman, B.D., Breshears, D.D., Gard, M.O., 2010. Evapotranspiration partitioning in a semiarid woodland: Ecohydrologic heterogeneity and connecitvity of vegetation patches. Vadose Zone Journal 9, 561-572.

Ngigi, S.N., 2003. What is the limit of up-scaling rainwater harvesting in a river basin? Physics and Chemistry of the Earth 28, 943-956.

Nicholson, S.E., 2011. Precipitation in the drylands, Dryland climatology. Cambridge University Press.

Noy-Meier, I., 1973. Desert ecosystems, environment, and producers. . Annual Review of Ecological Systems 4, 25-32.

Oweis, T., Hachum, A., 2009. Water Harvesting for Improved Rainfed Agriculture in the Dry Environments, in: Wani, S.P. (Ed.), Rainfed Agriculture: Unlocking the Potential. CAB International. 
Pandey, D.N., Gupta, A.K., Anderson, D.M., 2003. Rainwater harvesting as an adaptation to climate change. Current Science 85, 46-59.

Paraguay, G., 2013. Monitoreo de los cambios de uso de la tierra, incendios e inundaciones Gran Chaco Americano. In: Paraguay., G. (Ed.), Asunción.

Pasig, R., 2005. Origen y Dinámica del Agua Subterránea en el noroeste del Chaco Sudamericano (Chaco Tarijeño y oeste del Chaco Paraguayo).

Ploton, P., Pélissier, R., Proisy, C., Flavenot, T., Barbier, N., Rai, S., Couteron, P., 2012. Assessing aboveground tropical forest biomass using Google Earth canopy images.

Ecological Applications 22, 993-1003.

Raju, N.J., Reddy, T.V.K., Munirathnam, P., 2006. Subsurface dams to harvest rainwater - A case study of the Swarnamukhi River basin, Southern India. Hydrogeology Journal 14, 526-531.

Ripley, B.D., 2005. Spatial statistics. Wiley. com.

Rueda, C.V., Baldi, G., Verón, S.R., Jobbágy, E.G., 2013. Human appropriation of primary production in the Dry Chaco. Apropiación humana de la producción primaria en el Chaco Seco 23, 44-54.

Sanzano, G.A., Morandini, M., Hernández, C.F., Rojas Quinteros, H.C., Sosa, F.A., Hasán Jalil, A.J., Fadda, G.S., Devani, M.R., 2008. Efecto de la cobertura de rastrojos y las propiedades edáficas superficiales sobre la erosión hídrica en monocultivo de soja. Revista industrial y agrícola de Tucumán 85, 23-30.

Scanlon, B.R., Goldsmith, R.S., 1997. Field study of spatial variability in unsaturated flow beneath and adjacent to playas. Water Resources Research 33, 2239-2252.

Scanlon, B.R., Reedy, R.C., Stonestrom, D.A., Prudic, D.E., Dennehy, K.F., 2005. Impact of land use and land cover change on groundwater recharge and quality in the southwestern US. Global Change Biology 11, 1577-1593.

Toby Pennington, R., Prado, D.E., Pendry, C.A., 2000. Neotropical seasonally dry forests and Quaternary vegetation changes. Journal of Biogeography 27, 261-273. Tymkiw, P.T., 2010. Estudio técnico de alternativas de abastecimiento de agua al Chaco Central.

UMSEF, 2008. Monitoreo de la superficie de bosque nativo de Argentina., in: Secretaria de Ambiente y Desarrollo Sustentable, B.A. (Ed.).

UNEP, 2009. Rainwater harvesting: a lifeline for human well-being, in: Barron, J. (Ed.). United Nations Environment Programme.

Valentine, K., 1947. Distance from water as a factor in grazing capacity of rangeland. Journal of Forestry 45, 749-754.

Vallejos, M., Volante, J.N., Mosciaro, M.J., Vale, L.M., Bustamante, M.L., Paruelo, J.M., 2014. Transformation dynamics of the natural cover in the Dry Chaco ecoregion: A plot level geo-database from 1976 to 2012. Journal of Arid Environments. Von Hoyer, M., Junker, M., Centurion, C., Irrazabal-Soza, D., Larroza, F.A., Farina Larroza, S., Paredes-Rolon, J.L., 2000. Sustained water supply by artificial groundwater recharge in the chaco of paraguay. Zeitschrift für angewandte Geologie, 207-215. Walker, J.W., Heitschmidt, R., 1986. Effect of various grazing systems on type and density of cattle trails. Journal of Range Management, 428-431.

Weins, F., 2013. Chaco Paraguayo. Hidrogeología, Uso sustentable de los recursos hídricos para la producción agropecuaria del Chaco Paraguayo, Loma Plata, Paraguay. Weltzin, J.F., Loik, M.E., Schwinning, S., Williams, D.G., Fay, P.A., Haddad, B.M., Harte, J., Huxman, T.E., Knapp, A.K., Lin, G., Pockman, W.T., Shaw, M.R., Small, E.E., Smith, M.D., Smith, S.D., Tissue, D.T., Zak, J.C., 2003. Assessing the Response of Terrestrial Ecosystems to Potential Changes in Precipitation. BioScience 53, 941-952. Whitford, W., 2002. Caracterization of desert climates, in: Whitford, W. (Ed.), Ecology 
of desert systems, MRules, London.

Wiegand, T., Moloney, K., 2004. Rings, circles, and null-models for point pattern analysis in ecology. Oikos 104, 209-229.

Wilcox, B.P., Breshears, D.D., Allen, C.D., 2003. Ecohydrology of a resourceconserving semiarid woodland: Effects of scale and disturbance. Ecological Monographs 73, 223-239.

Zhang, S., Carmi, G., Berliner, P., 2013. Efficiency of rainwater harvesting of microcatchments and the role of their design. Journal of Arid Environments 95, 22-29. Zhang, Y., Chen, D., Chen, L., Ashbolt, S., 2009. Potential for rainwater use in high-rise buildings in Australian cities. Journal of Environmental Management 91, 222-226. 
Table 1. Impoundment types, catchment area types and storage capacity for each type of impoundment, for central Argentina and western Paraguay. Percentages of catchment areas do not sum $100 \%$, due to one impoundment could have more than one catchment area. * Values obtained from satellite data. ** Values estimated from field surveys.

\begin{tabular}{|c|c|c|c|c|c|c|c|c|c|c|c|c|c|}
\hline & \multirow[t]{2}{*}{ Type of impoundments } & & \multicolumn{5}{|c|}{ Catchment areas } & \multicolumn{6}{|c|}{ Impoundment storage capacity } \\
\hline & & & 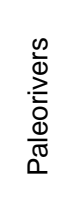 & 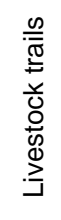 & $\begin{array}{l}\frac{0}{0} \\
\mathbb{1} \\
0 \\
\frac{0}{0} \\
\frac{0}{2} \\
\frac{0}{0}\end{array}$ & 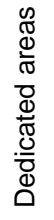 & 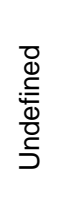 & $\begin{array}{l}{ }^{*} \\
\underline{\xi} \\
\bar{\Xi} \\
\stackrel{\Xi}{\Phi} \\
\unlhd\end{array}$ & $\begin{array}{l}\stackrel{*}{\xi} \\
\text { 岳 } \\
\frac{7}{3}\end{array}$ & 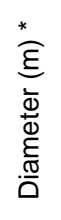 & 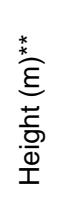 & 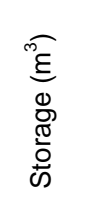 & $\begin{array}{l}\widehat{\circ} \\
\stackrel{0}{3} \\
0 \\
0 \\
0 \\
\frac{\pi}{0} \\
\text { ஸे }\end{array}$ \\
\hline \multirow{4}{*}{ 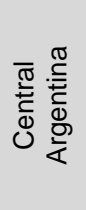 } & & $\%$ & & 82 & 98 & & & & & & & & \\
\hline & Horseshoe & 94 & & 84 & 98 & & & 75 & 41 & & 0,8 & 2460 & 82 \\
\hline & Rectangle & 6 & & 33 & 100 & & & 63 & 33 & & 1 & 2079 & 20 \\
\hline & Compound & & & & & & & & & & & & \\
\hline \multirow{4}{*}{ 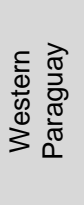 } & & $\%$ & 8 & 23 & 56 & 1 & 12 & & & & & & \\
\hline & Horseshoe & 1 & 100 & & & & & 80 & 15 & & 0,8 & 960 & \\
\hline & Rectangle & 75 & 9 & 30 & 45 & & 16 & 36 & 31 & & 1 & 1116 & 91 \\
\hline & Compound & 24 & 2 & & 92 & 4 & 2 & 65 & 44 & 28 & 4 & 4091 & 123 \\
\hline
\end{tabular}


Table 2. Rainwater harvesting systems density (mean, median and coefficient of variation) and the fraction located in dry forest and cleared lands, for central Argentina and western Paraguay. Different letters show significant differences between subregions ( $\mathrm{p}<0.01$; Tukey test).

\begin{tabular}{|c|c|c|c|c|c|}
\hline & \multicolumn{3}{|c|}{ Density (RWH systems $/ \mathrm{km}^{2}$ ) } & \multirow[b]{2}{*}{$\%$ in dry forest } & \multirow[b]{2}{*}{$\%$ in cleared } \\
\hline & mean & Median & CV (\%) & & \\
\hline Central Argentina & $0.098 \pm 0.039 \mathbf{a}$ & 0.074 & 80 & $94 \mathbf{b}$ & $6 \mathbf{a}$ \\
\hline Western Paraguay & $0.946 \pm 0.459 b$ & 0.458 & 97 & $24 a$ & $74 \mathrm{~b}$ \\
\hline
\end{tabular}




\section{Figure captions}

Figure 1. Dry Chaco ecoregion. White lines represent isolines of water availability (PPT:PET). Circles represent the sampling units within the two study areas, i.e. central Argentina and western Paraguay. Each circle represent a 10-km radius cell, in which detailed mapping was performed.

Figure 2. Library of rainwater harvesting systems from high spatial resolution images ( $<1-10 \mathrm{~m}$, Quickbird or World View to Spot images) available at Google Earth (A, B, C, $\mathrm{D}, \mathrm{E}, \mathrm{F}, \mathrm{G})$ and from photographs taken in the field (H, I). Horizontal bars represent $\sim 50$ m. A, B and C are impoundments of horseshoe, rectangle and compound types, respectively. D, E, F and G are catchment areas of paleorivers, livestock trails, vehicle roads, and dedicated area types (in $\mathrm{G}$ the arrows show the direction of runoff across the dedicated area). H: Typical low sophisticated impoundment of central Argentina, type horseshoe. I: High sophisticated rainwater harvesting system of western Paraguay, composed by an compound impoundment (rectangle and circular tank) and with vehicle roads as catchment areas.

Figure 3. Spatial distribution of rainwater harvesting systems for central Argentina (A) and western Paraguay (B), shown as the fraction of cells with clustered, dispersed and random distribution as a function of the radius from the rainwater harvesting system $(\mathrm{km})$.

Figure 4. Rainwater harvesting systems as a function of the fraction of cleared surface land (A) and distance to villages (B), for central Argentina and western Paraguay. Each marker represents one cell (unit of analysis). The equations and the regression coefficient shown correspond to western Paraguay (the only with significant association; $\mathrm{p}<0.0001)$.

Figure 5. Temporal dynamic of precipitation events (A), impoundment water level (B) and tank evaporation (C), from a period of 18 month (2011-2013). Water level was measured in a horseshoe impoundment type in central Argentina.

Figure 6. A. Water gain $\left(\mathrm{m}^{3}\right)$ as a function of the precipitation magnitude (mm). B. 
Water loss $\left(\mathrm{m}^{3} /\right.$ day) as a function of impoundment water level $(\mathrm{mm})$. Both measurements were taken in a horseshoe impoundment, in central Argentina. 


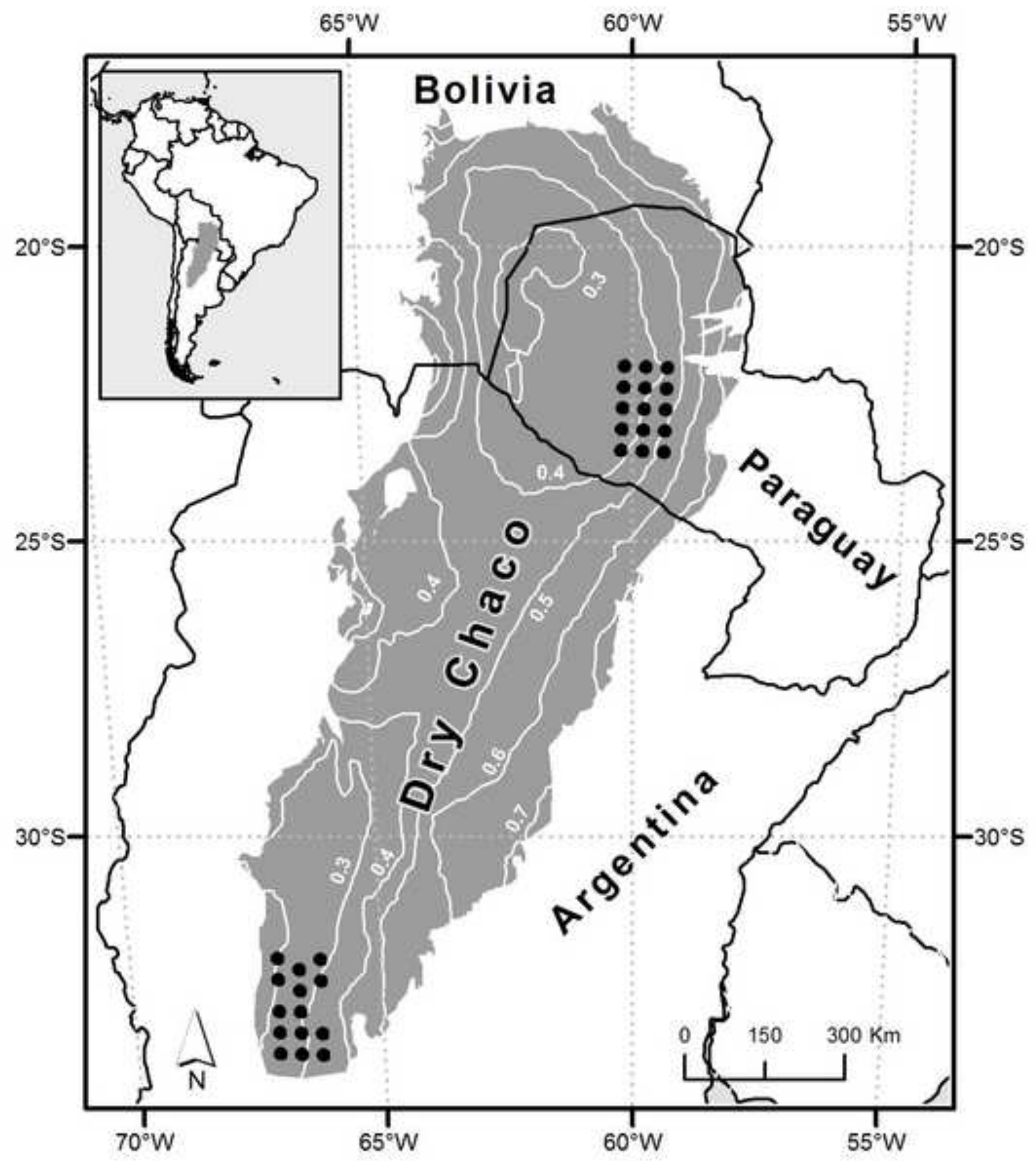



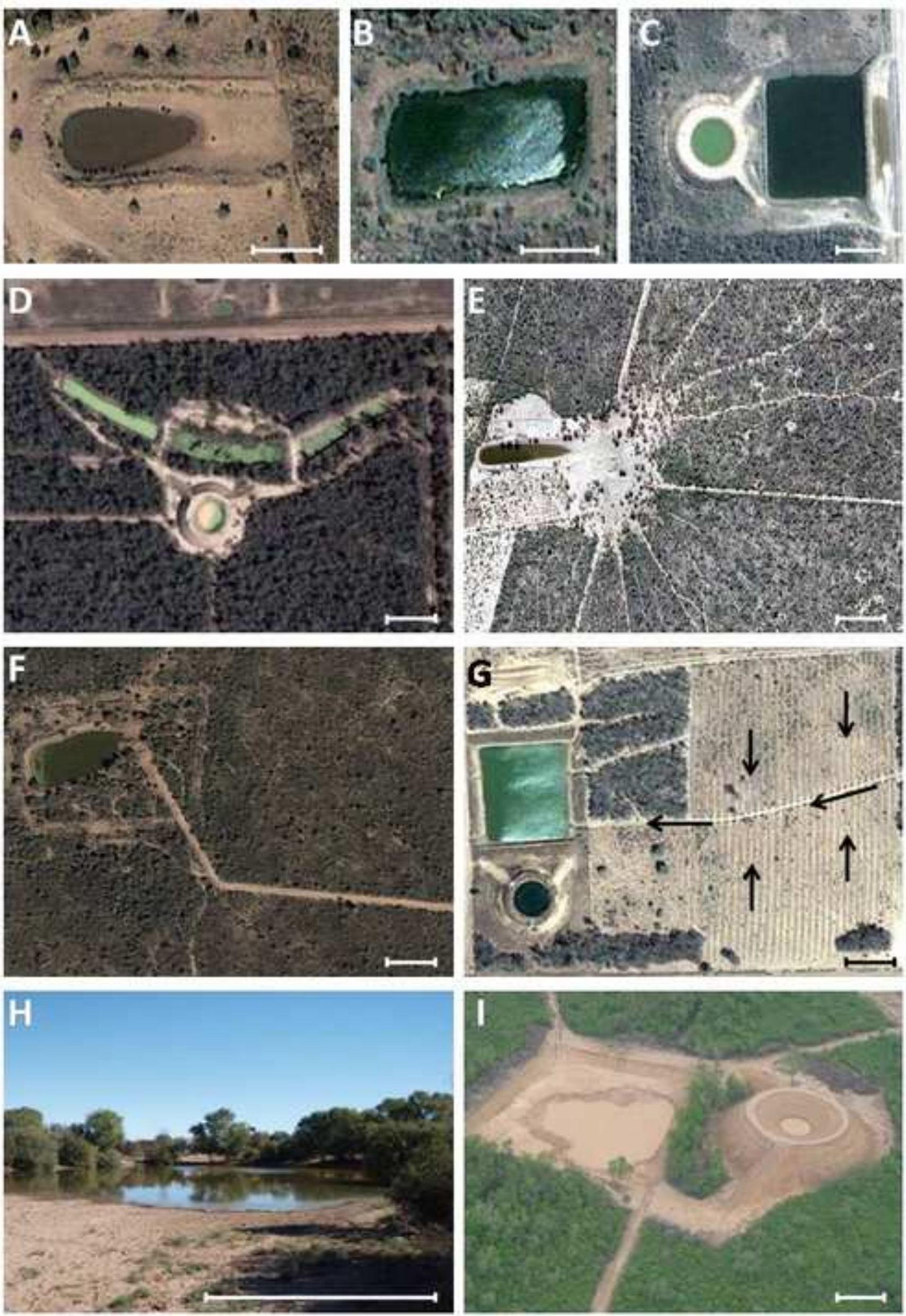

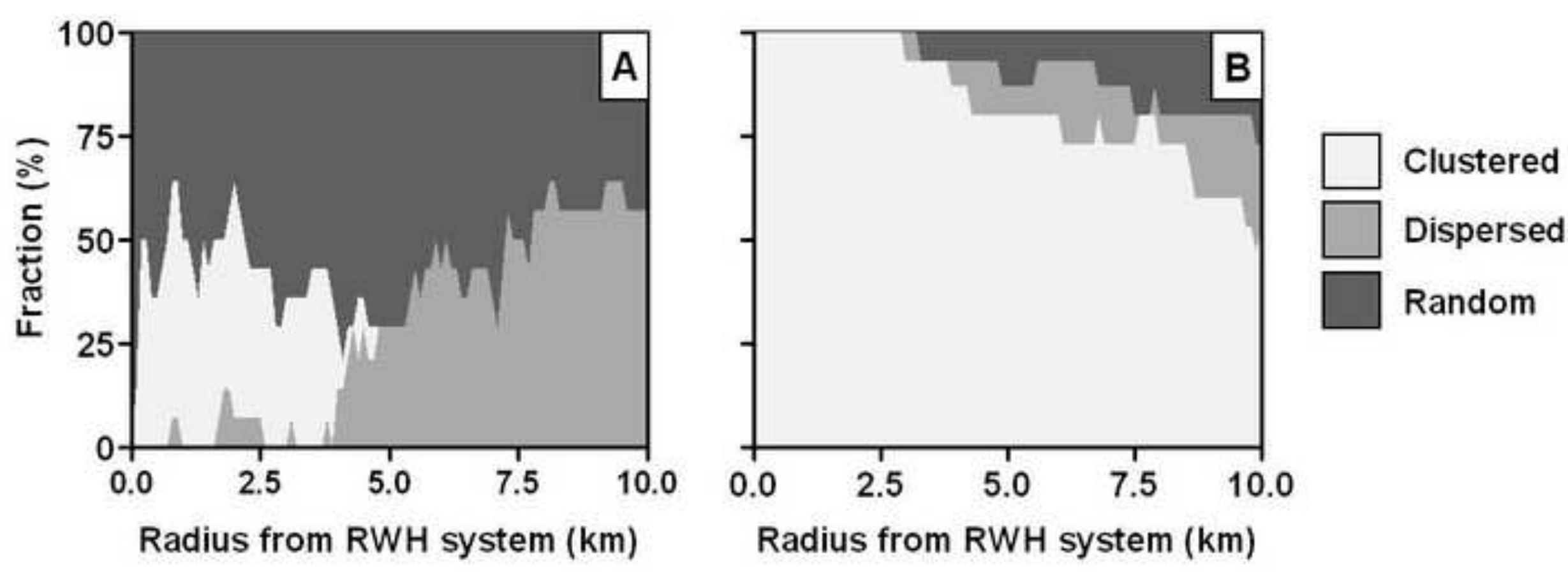

Radius from RWH system (km) Dispersed Random 
ह

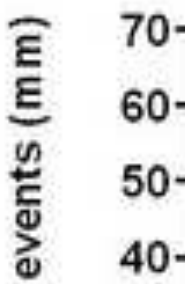
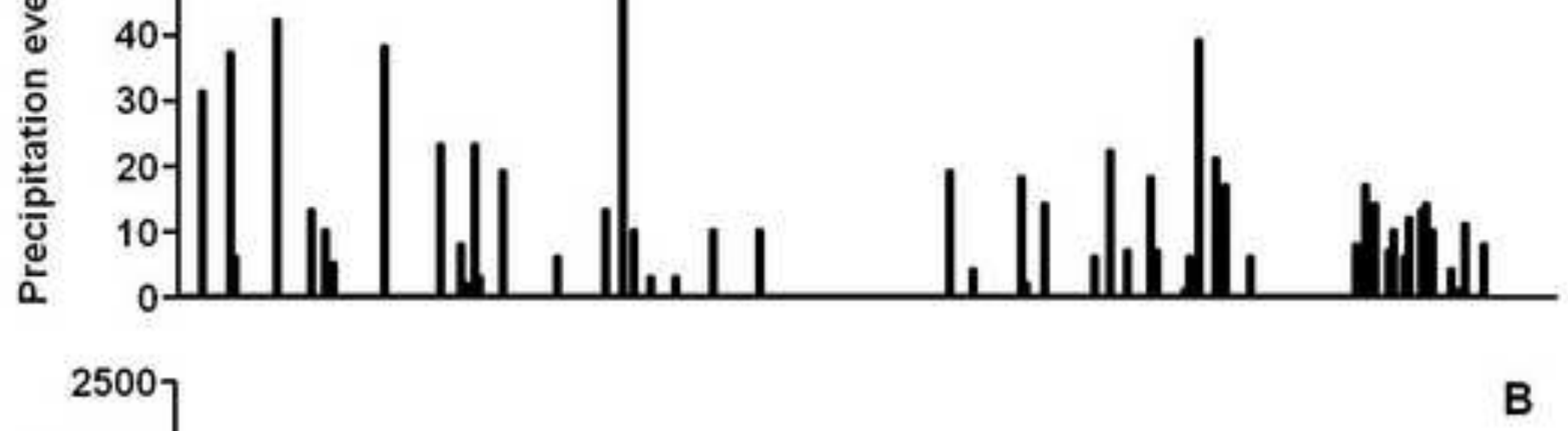

S

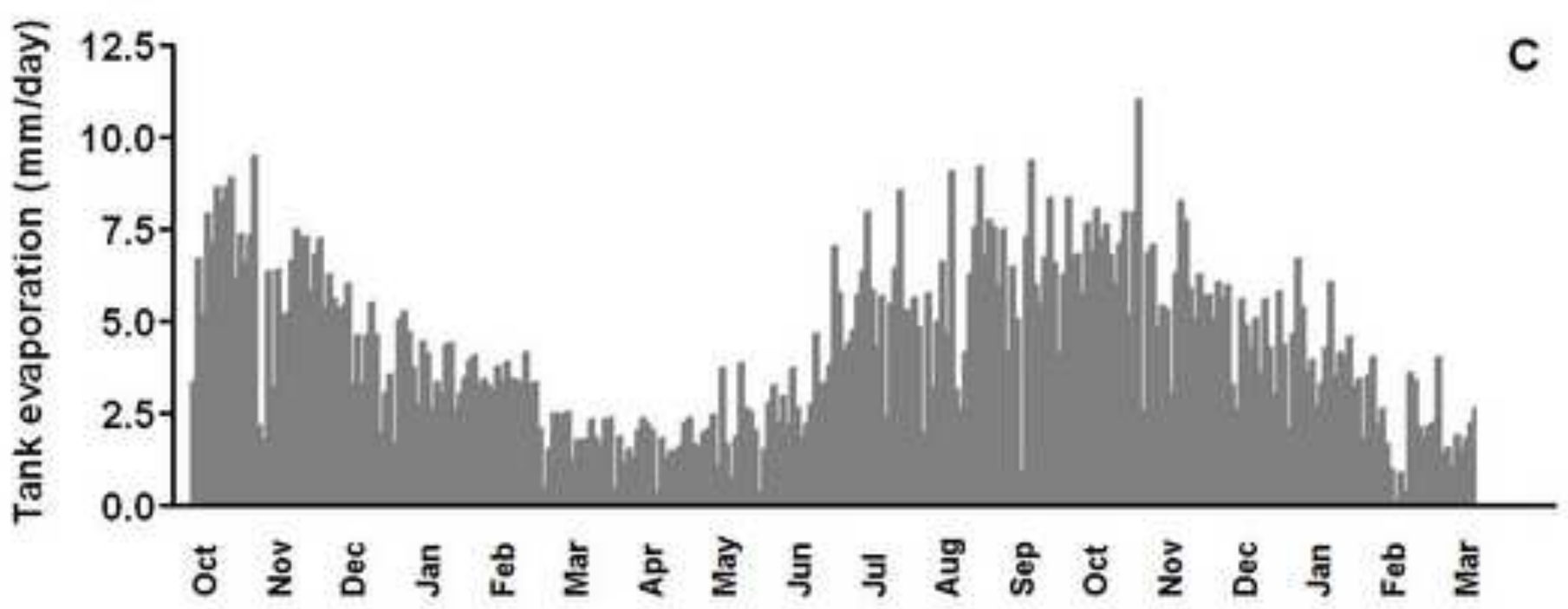



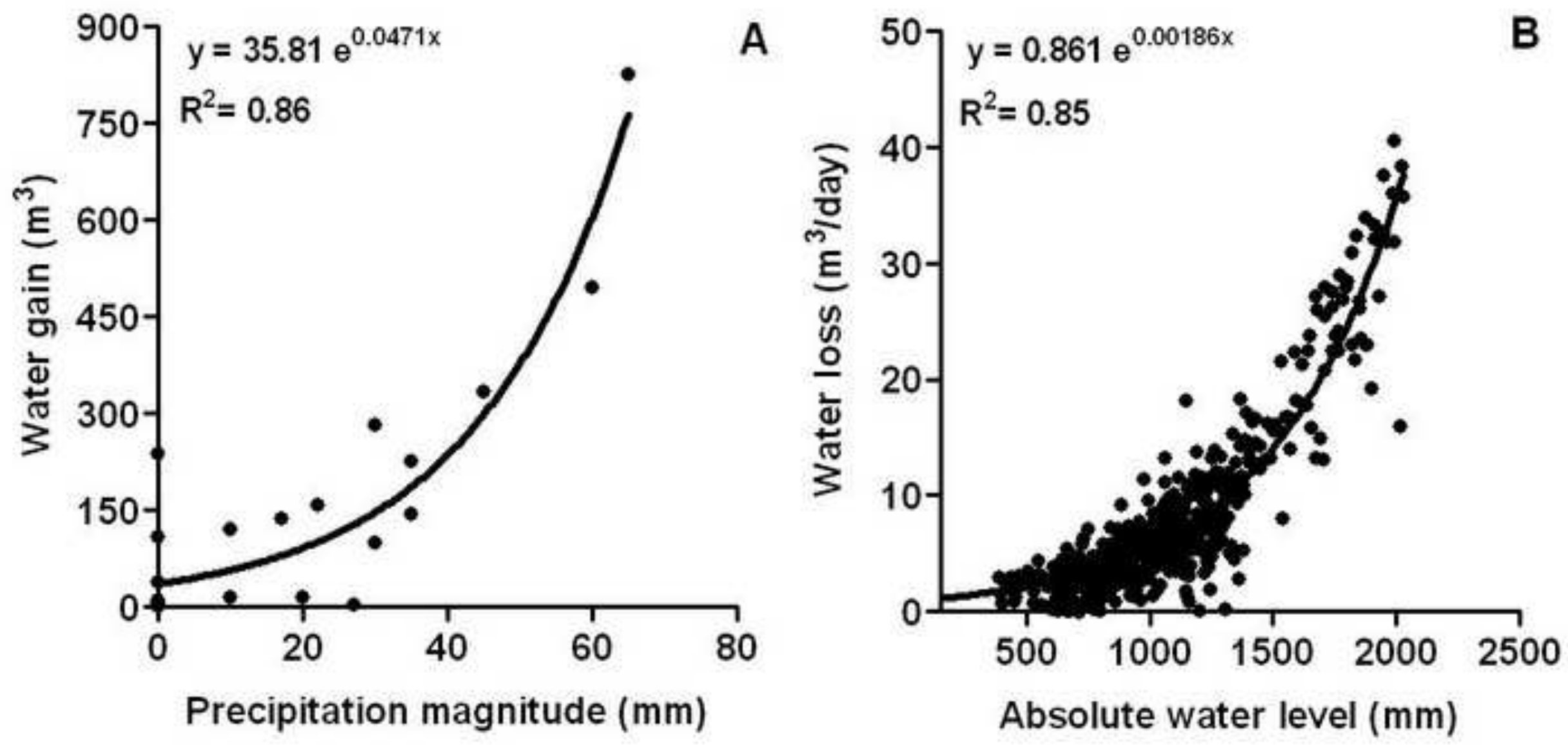